\title{
Doing Better by Doing Good: Discussing the Value Potential of Selected "Just Companies"
}

\author{
Hafiz Imtiaz Ahmad ${ }^{1}$ \\ ${ }^{1}$ Higher Colleges of Technology, AL Ain, Abu Dhabi, UAE \\ Correspondence: Hafiz Imtiaz Ahmad, PhD., CVA, CPVA, BCA, MAFF, Higher Colleges of Technology, AL Ain, \\ Abu Dhabi, UAE.
}

Received: November 24, 2019

Accepted: December 24, 2019

Online Published: March 16, 2020

doi:10.5430/ijfr.v11n2p40

URL: https://doi.org/10.5430/ijfr.v11n2p40

\begin{abstract}
On December 10, 2018, The JUST Capital Foundation, in partnership with Forbes, has released the 2018 ranking of the one hundred most socially "just" companies in the United States (Forbes; Just capital Foundation, 2018).This paper aims to discuss the value generation potential of the selected companies in this list by using (Ohlson, 1995) model. Our findings suggest that the in the context of USA, markets value social responsibility efficiently and the impact is visible in various sectors. These results may be of interest for investment analysts, academic researchers, Governments and regulatory bodies. In addition, we suggest that the results may indicate an area into which valuation professionals should invest time and thought as they assess the values of privately-held companies.
\end{abstract}

Keywords: valuation, corporate social responsibility, just companies

\section{Introduction}

On December 10, 2018, The JUST Capital Foundation, in partnership with Forbes, released the 2018 ranking of the one hundred most socially "just" companies in the United States (Forbes; Just capital Foundation, 2018). This ranking was based on a survey of 81000 Americans who were asked what they thought the most important corporate attributes were: JUST Capital and Forbes ranked nearly nine hundred of the largest publicly traded companies in the U.S. on thirty-six of those attributes grouped into seven categories - job creation, worker pay and benefits, customer treatment, product pricing and quality, environmental impact, contribution to community well-being, and ethical leadership. Microsoft ranked first overall, followed by Intel and Alphabet, the parent company of Google (McGrath \& Konrad, 2018).

This paper aims to discuss the value generation potential of the selected companies in this list from a different lens. To accomplish this objective, (Ohlson, 1995) model has been used to verify the value generation potential of these selected companies. The goal here is to observe the impact of socially responsible companies on their market price.

The JUST Capital Foundation, Inc. (http://justcapital.com) is an independent, nonprofit 501(c) (3) organization that works to align business practices with the American people to ensure capitalism works for all. Co-founded in 2013 by a group of concerned people from the world of business, finance, and civil society - including Chairman Paul Tudor Jones II, Deepak Chopra, Rinaldo Brutoco, Arianna Huffington, Paul Scialla, and others - JUST Capital ranks how the largest, publicly traded U.S. corporations measure up against the American people's definition of just business behavior, and provides research, indexes, and data-driven tools to help people make more informed decisions about where to invest, work, and buy to direct capital toward companies advancing a more just future. The organization is based in New York City.

Corporate social responsibility (CSR) is known as voluntary actions taken by the company to integrate environmental and social concerns into the business and to achieve sustainability in the long-run (ACCA, 2015). The concept of triple bottom line "People, Planet and Profit" (Zak, 2015) considers the important factors that contribute to a company's success other than the purely financial ones.

According to recent study by CFA Institute (CFA Institute, 2018), many of the emerging trends for the next 5-10 years are based on changing client expectations, as seen in some of the key survey findings among CFA members: $72 \%$ expect their firm's future commitment to the research of environmental, sustainability, and governance (ESG) issues to be higher. 
CSR activities may benefit companies long term through a better image and good reputation in the public, even if such activities require some near-term sacrifice of profit. Good corporate image may help workers to achieve higher self-esteem and work more efficiently and achieve higher productivity and it helps to attract a good talent (Stubes \& Sun, 2010). Good CSR policies could lead to higher stock returns since there is a positive relationship between CSR activities and the return of the adjusted market in the subsequent period. Prior studies have also suggested that commitment to CSR enhances firm's ability to perform better in short and long run (Yu \& Choi, 2014; Cheng, Ioannou, \& Serafeim, 2014).

We, in this study, employ (Ohlson, 1995) model for the purpose of valuation of "Just Companies". Since its introduction in 1995, (Ohlson, 1995) model has become a reference point in equity valuation and capital market research. The model has been used by academics, practitioners, and policy makers, alike. The beauty of the model lies in its simplicity. This model traces the value of the company in the accounting data by summing two components - accounting book value and the discounted value of future residual income. The latter part captures all the other information that can affect the stock market price of a firm, other than accounting data ( (Preinrich, 1938); (Edward \& Bell, 1961); (Peasnell, 1982)). In addition, (Ohlson, 1995) depicts price as a linear combination of equity book value and earnings weighted by earning persistence. According to (Ohlson, 1995) there is a direct relationship between persistence of earnings and pricing multiples. The more persistent the earnings reported, the larger the pricing multiples.

The structure of our work, in this study, is as follows: Section 2 briefs readers about the literature review and hypotheses; Section 3 brings into light our research design and data collection methodology; and Section 4 unfolds and depicts the results. We conclude and summarize our findings in Section 5. This last section also provides insights, stimulus and motivation for future research.

\section{Literature Review and Hypothesis}

\section{1 (Ohlson, 1995) Model}

The roots of Ohlson (1995) model can be found in the basic dividend discount model as expressed follows:

$$
P_{t}=\sum_{t=1}^{\infty} \frac{E\left[d_{t+\tau}\right]}{(1+R)^{\tau}}(P V E D)(1)
$$

Where $\mathrm{E}[\ldots]$ denotes the expectation operator. This model permits negative $\mathrm{d}(\mathrm{t})$ that reflects capital contributions. The $\mathrm{d}(\mathrm{t})$ should, in fact, be referred to as dividends net of capital contribution but we will keep referring it to simply dividends for the sake of brevity. PVED is an equilibrium condition. It is a no-interpersonal arbitrage price that results when interest rates are not stochastic, beliefs are homogenous and investors are risk neutral. It is also the first assumption of the (Ohlson, 1995) model.

The clean surplus accounting (CSA) method provides elements of a forecasting model that yields price as a function of earnings, expected returns, and change in book value. The CSA is the second assumption of the (Ohlson, 1995) model and can be stated as:

$$
\begin{gathered}
b v_{t}=b v_{t-1}+x_{t}-d_{t}(C S A) \\
\text { Or } d_{t}=b v_{t-1}-x_{t}-b v_{t} \\
\text { Or } d_{t+\tau}=b v_{t-1+\tau}+x_{t+\tau}-b v_{t+t}
\end{gathered}
$$

Where:

$\mathrm{bv}_{\mathrm{t}}=$ book value of the firm's equity, date $\mathrm{t}$

$x_{t}=$ earnings for period $(t-1, t)$

$d_{t}=$ dividend, net of capital contribution, date $t$

Moving ahead from this development residual income $\left(x_{t}^{a}\right.$ at date $\left.t\right)$ can be defined as the difference between net income and capital charge at the discount R:

$$
\begin{gathered}
x_{t}^{a}=x_{t}-R_{b v_{t}-1} \\
\text { Or } x_{t+\tau}^{a}=x_{t+\tau}-R b v_{t-1+\tau}(R I)
\end{gathered}
$$

Substituting the value of $x_{t+\tau}$ is from equation 4 to equation 3 
(4) in (3):

$$
\begin{aligned}
& d_{t+\tau}=b v_{t-1+\tau}+x_{t+\tau}^{a}+R b v_{t-1+\tau}-b v_{t+\tau} \\
& \text { Or } d_{t+\tau}=(1+R) b v_{t-1+\tau}+x_{t+\tau}^{a}-b v_{t+\tau}
\end{aligned}
$$

Combining PVED $\left(d_{t+\tau}\right)$ and $\mathrm{RI}\left(x_{t+\tau}^{a}\right)$ we get the residual income valuation model as:

$$
\begin{gathered}
P_{t}=\sum_{\tau=1}^{\infty} \frac{E\left[(1+R) b v_{t+\tau-1}-b v_{t+\tau}+x_{t+\tau}^{a}\right]}{(1+R)^{\tau}} \\
\text { Or } P_{t}=\sum_{\tau=1}^{\infty} \frac{E\left[b v_{t+\tau-1}\right]}{(1+R)^{\tau-1}}-\sum_{\tau=1}^{\infty} \frac{E\left[b v_{t+\tau}\right]}{(1+R)^{\tau}}+\sum_{\tau=1}^{\infty} \frac{E\left[x_{t+\tau}^{a}\right]}{(1+R)^{\tau}}
\end{gathered}
$$

Residual Income can be written in terms of total income and book value:

$$
\begin{aligned}
& \mathrm{P}_{\mathrm{t}}=\mathrm{bv}_{\mathrm{t}}+\sum_{\tau=1}^{\infty} \frac{\mathrm{E}\left[\mathrm{bv}_{\mathrm{t}+\varnothing]}\right.}{(1+\mathrm{R})^{\phi}}-\sum_{\tau=1}^{\infty} \frac{\mathrm{E}\left[\mathrm{bv}_{\mathrm{t}+\tau]}\right]}{(1+\mathrm{R})^{\tau}}+\sum_{\tau=1}^{\infty} \frac{\mathrm{E}\left[\mathrm{x}_{\mathrm{t}+\tau}^{\mathrm{a}}\right]}{(1+\mathrm{R})^{\tau}} \\
& \text { Or } P_{t}=b v_{t}+\sum_{\tau=1}^{\infty} \frac{E\left[x_{t+\tau}^{a}\right]}{(1+R)^{\tau}}(R I V)
\end{aligned}
$$

The RIV equation was first presented by (Preinrich, 1938). The point worth noting in RIV is the change of focus from wealth distribution (Dividends) (PVED) to wealth creation (residual income) that take into accounts various operational efficiencies including CSR activities.

Linear information model (LIM) is the main contribution to valuation theory by Ohlson. A simple linear information model formulates the dynamics of residual income and information "other than" residual income, $\vartheta_{t}$.

$$
\begin{gathered}
x_{t+1}=\omega x_{t}^{a}+\vartheta_{t}+\epsilon_{1 t} \\
\vartheta_{t+1}=\gamma \vartheta_{t}+\epsilon_{2 t}
\end{gathered}
$$

Where the disturbance terms $\epsilon_{1 t}$ and $\epsilon_{2 t}$ are two non-zero random variables and where the parameter $\omega$

and $\gamma$ are fixed and known in the sense that the firm's accounting principles and economic environment determine their values.

Equation no.7 is also known as the third assumption of the (Ohlson, 1995) model. According to this assumption, both abnormal earnings and non-accounting information are autoregressive. To be precise $\vartheta_{t}$ can be written as:

$$
\vartheta_{\mathrm{t}}=\mathrm{E}\left[\mathrm{x}_{\mathrm{t}+1}^{\mathrm{a}}\right]-\omega_{\mathrm{t}}^{\mathrm{a}}
$$

And, this is interpreted as unpredicted growth.

Finally, the (Ohlson, 1995) linear function is given as:

$$
\mathrm{P}_{\mathrm{t}}=\mathrm{bv}_{\mathrm{t}}+\alpha_{1} \mathrm{x}_{\mathrm{t}}^{\mathrm{a}}+\alpha_{2} \vartheta_{\mathrm{t}}(\mathrm{OM})
$$

Where:

$$
\begin{gathered}
\alpha_{1}=\frac{\omega}{1+\mathrm{R}-\omega} ; \\
\alpha_{2}=\frac{1+\mathrm{R}}{(1+\mathrm{R}-\omega)(1+\mathrm{R}-\gamma)} \\
\vartheta_{1 \mathrm{t}}=^{\prime} \text { Other information' variable at time } \mathrm{t} \\
\omega=\text { Persistence of abnormal earnings }(0<\omega<1) \\
\gamma=\text { Persistence of 'Other information' }(0<\gamma<1)
\end{gathered}
$$

It is important to note that in this paper, we consider that Ohlson 1995 model can only be applied to the firm with abnormal profits. If the model is used for firms with abnormal losses, the resulting intrinsic value would be lower than the book value of equity.

From the empirical standpoint, the (Ohlson, 1995) demands three variables $\left(b v_{t}, x_{t}\right.$ and $\left.\vartheta_{t}\right)$ and three parameters $(\omega, \gamma$ and $k)$ to be known. 
In this study, we employ the methodology of (Dechow, Hutton, \& Sloan, 1999) for the estimation of these parameters and variables. Consistent to their work, we consider $\vartheta_{t}$ i.e., other information to be zero. This consideration leads the parameter of other information ' $\gamma$ ' to be zero, as well, and in OM equation, this hypothesis make $\alpha_{2}=0$. This assumption yields the following empirical version of (Ohlson, 1995) model:

$$
P_{t}=\alpha_{o}+\alpha_{1} b v_{t}+\alpha_{2} x_{t}^{a}+\varepsilon_{1 t}
$$

The above valuation function has been scaled by assets to avoid a size effect. Hence, our required valuation equation in this study would be:

$$
\frac{P_{t}}{\text { Total assets }}=\alpha_{o}+\frac{\alpha_{1} b v_{t}}{\text { Total assets }}+\frac{\alpha_{2} x_{t}^{a}}{\text { Total assets }}+\varepsilon_{1 t}
$$

\subsection{Corporate Social Responsibility and Valuation of Firms}

Corporate social responsibility and its relationship to valuation of the firm has been the focus of many research studies published recently. Companies, investors and research scholars have asked one fundamental question: does it increase entity value to engage in social responsibility? The results obtained by various research work are mixed for both developed and developing countries but three main dimensions emerge from the literature (positive, negative and neutral). These mixed results are due to differences in approaches and focus of the studies (Park, 2017).

The positive relationship between CSR and firm value/performance can be found in stakeholder theory. (Alikaj, Nguyen, \& Medina, 2017) found that when correlation between CSR and financial performance is analyzed using accounting-based, market-based and investor-based measures, engagement in CSR may raise the firm valuation. Research indicates that CSR builds good reputation which translates into positive valuation for the firm. (Cheung, 2010). Investment in CSR can provide "insurance-like" benefits (Godfrey, Merrill, \& Hansen, 2009)). Reducing waste, for instance, is a way to avoid environmental disasters, financial lawsuits and consumer boycotts as well as to reduce costs.

The neoclassical economic school of thought and utility theory argue that CSR activities do not enhance the value of the firm. According to (Famiyeh, 2017), CSR related cost could be retained or the same resources could be allocated to other agents e.g., customers and governments. Thus, the economic advantages of spending on CSR related activities are limited. (Weber, 2008) argues that financial implications of doing good are mixed. Doing good is profitable for a firm if the financial benefits from this behavior are higher than its costs. The link between CSR and firm value is therefore strongly theoretically grounded in a discounted marginal cash flow analysis. What impact does CSR have on the discount rate? As investors estimate that risk decreases when social behaviors are undertaken, the discount rate also decreases, increasing firm value.

(Oeyono, Samy, \& Bampton, 2011) state that the relationship between CSR and financial performance is neutral, where additional costs incurred by implementing social responsibility are exactly matched by gains arising from it. (Horváthová, 2010) found that the positive and negative views of CSR are called into question by a third stream of literature, which postulates an inverted U-shaped relationship between performance and CSR practices( (Lankoski, 2000), (Wagner, 2001)). Investing in CSR can be rewarding until profit is maximized. After this point, costs increase more than profits, which lead to fewer benefits. For other authors like (McWilliams \& Siegel, 2001), there is a neutral relationship between CSR and performance.

\subsubsection{Valuation of "Just Companies"}

Table 1 below that covers the issues that were considered for selection of "Just Companies" by Just Foundation. In this context, we investigate the following hypotheses in this paper:

1- Markets do not value corporate social responsibility at all

2- Markets value corporate social responsibility efficiently

3- Markets value corporate social responsibility but do not value it efficiently

Table 1. Issues covered in the selection of "Just Companies" with their scoring weights

\begin{tabular}{lll}
\hline Issues & Explanation & $\begin{array}{c}\text { Scoring } \\
\text { Weight }\end{array}$ \\
\hline Workers & Workers are the top priority for just companies, according to the American public, & $25 \%$ \\
\hline
\end{tabular}


who believe employees should receive benefits, earn fair and equal pay, and work in a safe environment.

\begin{tabular}{|c|c|c|c|}
\hline Customers & & $\begin{array}{l}\text { Americans believe that companies should do right by their customers, whose } \\
\text { weight is second only to workers' in our scoring model. According to our survey, } \\
\text { fair treatment, customer privacy, and truthful advertising are essential to just } \\
\text { business behavior. }\end{array}$ & $18 \%$ \\
\hline Products & & $\begin{array}{l}\text { The products and services offered by a company are an essential measure of its just } \\
\text { business practices, according to Americans. They believe that companies should } \\
\text { offer fair pricing, accurate labeling, and products that benefit health, environment, } \\
\text { or society }\end{array}$ & $14 \%$ \\
\hline Environment & & $\begin{array}{l}\text { Americans see the planet as a key stakeholder, and agree that corporations play a } \\
\text { role in protecting our planet - minimizing pollution, reducing waste, and } \\
\text { implementing robust environmental management systems. }\end{array}$ & $13 \%$ \\
\hline Jobs & & $\begin{array}{l}\text { The creation of quality jobs is central to just business practices, with Americans } \\
\text { agreeing that companies should create and maintain jobs both globally and in the } \\
\text { United States. }\end{array}$ & $12 \%$ \\
\hline Communities & & $\begin{array}{l}\text { Americans believe that companies should support the communities they impact, } \\
\text { both at home and abroad. Through addressing the negative social impacts from } \\
\text { supply chains (such as labor rights abuses and conflict minerals), supporting local } \\
\text { suppliers, and giving back through charitable giving and volunteering, companies } \\
\text { should foster and protect the communities they impact and the people who live } \\
\text { there. }\end{array}$ & $11 \%$ \\
\hline $\begin{array}{l}\text { Company } \\
\text { Leadership } \\
\text { Shareholders }\end{array}$ & \& & $\begin{array}{l}\text { Americans prioritize just and ethical leadership within companies, including fair } \\
\text { CEO-to-Worker pay ratios and adherence to laws and regulations, as well as } \\
\text { long-term financial growth and value creation for shareholders. }\end{array}$ & $8 \%$ \\
\hline
\end{tabular}

We, accomplish this objective by selecting representative firms from each industry sector in the USA that are already part of "Just Companies" and checking their value generation potential.

\section{Research Design and Data Collection}

This section describes the data and methodology used to empirically investigate the link between corporate social responsibility and equity asset valuation. We selected top five representative firms (from "Just Companies" index) covering 33 industrial sectors of USA economy. Relevant data (stock prices) were collected for each firm for years (2013-2018). This data is used to get graph from Yahoo finance. In total 165 leading companies from each sector were selected with 990 firm years for the purpose of this study. The selected companies with their respective tickers are listed below:

Table 2. Name and tickers of selected "Just Companies" from all the industry sectors of USA

\begin{tabular}{lll}
\hline $\mathbf{1}$ & Aero Space & Ticker \\
\hline 1 & Northrop Grumman & NOC \\
\hline 2 & Boeing & BA \\
\hline 3 & Raytheon & RTN \\
\hline 4 & Lockheed Martin & LMT \\
\hline 5 & Huntington Ingalls & HII \\
\hline $\mathbf{2}$ & Automobiles \& Parts & Ticker \\
\hline 1 & General Motors & GM \\
\hline 2 & Ford Motor & F \\
\hline 3 & Valvoline & VVV \\
\hline 4 & Aptiv & APTV
\end{tabular}

\begin{tabular}{lll}
\hline $\mathbf{8}$ & Chemicals & Ticker \\
\hline 1 & DowDuPont & DWDP \\
\hline 2 & Avery Dennison & AVY \\
\hline 3 & International Flavors \& Fragrances & IFF \\
\hline 4 & Albemarle & ALB \\
\hline 5 & Ecolab & ECL \\
\hline $\mathbf{9}$ & Commercial Support Services & Ticker \\
\hline 1 & Accenture & ACN \\
\hline 2 & Johnson Controls & JCI \\
\hline 3 & PayPal Holdings & PYPL \\
\hline 4 & Xerox & XRX \\
\hline & &
\end{tabular}




\begin{tabular}{|c|c|c|}
\hline 5 & Lear Corp & LEA \\
\hline 3 & Banks & Ticker \\
\hline 1 & Bank of America & $\mathrm{BAC}$ \\
\hline 2 & Comerica & CMA \\
\hline 3 & JPMorgan Chase & JPM \\
\hline 4 & Citigroup & $\mathrm{C}$ \\
\hline 5 & Regions Financial & RF \\
\hline 4 & Basic Resources & Ticker \\
\hline 1 & Freeport-McMoRan & FCX \\
\hline 2 & Alcoa & \\
\hline 3 & Newmont Mining & NEM \\
\hline 4 & Domtar & UFS \\
\hline 5 & Nucor & NUE \\
\hline 5 & Building Materials \& Packaging & Ticker \\
\hline 1 & Owens Corning & $\mathrm{OC}$ \\
\hline 2 & Ball Corp & BLL \\
\hline 3 & Fortune Brands Home \& Security & FBHS \\
\hline 4 & AptarGroup & ATR \\
\hline 5 & Sherwin-Williams & SHW \\
\hline 6 & Industrial Goods & Ticker \\
\hline 1 & Keysight Technologies & KEYS \\
\hline 2 & $3 \mathrm{M}$ & MMM \\
\hline 3 & Agilent Technologies & A \\
\hline 4 & Fluor & FLR \\
\hline 5 & General Electric & GE \\
\hline 7 & Capital Markets & Ticker \\
\hline 1 & Bank of New York Mellon & BK \\
\hline 2 & State Street & STT \\
\hline 3 & Legg Mason & $\mathrm{LM}$ \\
\hline 4 & Charles Schwab & SCHW \\
\hline 5 & Voya Financial & VOYA \\
\hline 15 & Food, Beverage \& Tobacco & Ticker \\
\hline 1 & General Mills & GIS \\
\hline 2 & Kellogg & $\mathrm{K}$ \\
\hline 3 & Campbell Soup & CPB \\
\hline 4 & PepsiCo & PEP \\
\hline 5 & Hershey & HSY \\
\hline 16 & $\begin{array}{l}\text { Health Care Equipment \& } \\
\text { Services }\end{array}$ & Ticker \\
\hline 1 & ResMed & RMD \\
\hline 2 & Varian Medical Systems & VAR \\
\hline 3 & Edwards Lifesciences & EW \\
\hline 4 & Baxter International & BAX \\
\hline 5 & Medtronic & MDT \\
\hline & Health Care Providers & Ticker \\
\hline
\end{tabular}

\begin{tabular}{|c|c|c|}
\hline 5 & Alliance Data Systems & ADS \\
\hline 10 & Consumer \& Diversified Finance & Ticker \\
\hline 1 & S\&P Global & SPGI \\
\hline 2 & Visa & $\mathrm{V}$ \\
\hline 3 & American Express & AXP \\
\hline 4 & MasterCard & MA \\
\hline 5 & Synchrony Financial & SYF \\
\hline 11 & Household Goods \& Apparel & Ticker \\
\hline 1 & Nike & NKE \\
\hline 2 & PVH Corp & $\mathrm{PVH}$ \\
\hline 3 & Hasbro & HAS \\
\hline 4 & Stanley Black \& Decker & SWK \\
\hline 5 & Whirlpool & WHR \\
\hline 12 & Restaurants \& Leisure & Ticker \\
\hline 1 & Hilton & HLT \\
\hline 2 & Marriott International & MAR \\
\hline 3 & Starbucks & SBUX \\
\hline 4 & Expedia & EXPE \\
\hline 5 & TripAdvisor & TRIP \\
\hline 13 & Energy Equipment \& Services & Ticker \\
\hline 1 & Baker Hughes & BHGE \\
\hline 2 & ONEOK & OKE \\
\hline 3 & Schlumberger & SLB \\
\hline 4 & Halliburton & HAL \\
\hline 5 & Williams & WMB \\
\hline 14 & Food \& Drug Retailers & Ticker \\
\hline 1 & Cardinal Health & $\mathrm{CAH}$ \\
\hline 2 & CVS Health & CVS \\
\hline 3 & Sysco & SYY \\
\hline 4 & Walgreens Boots Alliance & WBA \\
\hline 5 & McKesson & MCK \\
\hline 29 & Software & Ticker \\
\hline 1 & Microsoft & MSFT \\
\hline 2 & VMware & VMW \\
\hline 3 & Adobe Inc & ADBE \\
\hline 4 & salesforce.com & CRM \\
\hline 5 & Intuit & INTU \\
\hline 30 & Technology Hardware & Ticker \\
\hline 1 & Cisco Systems & $\mathrm{CSCO}$ \\
\hline 2 & Apple & AAPL \\
\hline 3 & HP Inc & HPQ \\
\hline 4 & Juniper Networks & JNPR \\
\hline 5 & Pure Storage & PSTG \\
\hline
\end{tabular}




\begin{tabular}{lll}
\hline 1 & Humana & HUM \\
\hline 2 & UnitedHealth Group & UNH \\
\hline 3 & Cigna & CI \\
\hline 4 & Anthem & ANTM \\
\hline 5 & HCA Holdings & HCA \\
\hline $\mathbf{1 8}$ & Personal Products & Ticker \\
\hline 1 & Procter \& Gamble & PG \\
\hline 2 & Kimberly-Clark & KMB \\
\hline 3 & Colgate-Palmolive & CL \\
\hline 4 & Clorox & CLX \\
\hline 5 & Estee Lauder & EL \\
\hline $\mathbf{1 9}$ & Insurance & Ticker \\
\hline 1 & Prudential Financial & PRU \\
\hline 2 & Principal Financial Group & PFG \\
\hline 3 & MetLife & MET \\
\hline 4 & Hartford Financial & HIG \\
\hline 5 & Travelers & TRV \\
\hline $\mathbf{2 0}$ & Internet & Ticker \\
\hline 1 & Alphabet & GOOG \\
\hline 2 & Facebook & FB \\
\hline 3 & Akamai Technologies & AKAM \\
\hline 4 & Twitter & TWTR \\
\hline 5 & GoDaddy & GDDY \\
\hline $\mathbf{2 1}$ & Computer Services & Ticker \\
\hline 1 & International Business Machines & IBM \\
\hline 2 & Hewlett Packard Enterprise & HPE \\
\hline 3 & Teradata & TDC \\
\hline 4 & Leidos Holdings & LDOS \\
\hline 5 & Cognizant Technology Solutions & CTSH \\
\hline & & \\
\hline
\end{tabular}

\begin{tabular}{lll}
\hline $\mathbf{3 1}$ & Telecommunications & Ticker \\
\hline 1 & AT\&T & $\mathrm{T}$ \\
\hline 2 & Verizon Communications & VZ \\
\hline 3 & T-Mobile US & TMUS \\
\hline 4 & Sprint & $\mathrm{S}$ \\
\hline 5 & CenturyLink & CTL \\
\hline $\mathbf{3 2}$ & Transportation & Ticker \\
\hline 1 & United Parcel Service & UPS \\
\hline 2 & Delta Air Lines & DAL \\
\hline 3 & FedEx & FDX \\
\hline 4 & Southwest Airlines & LUV \\
\hline 5 & Union Pacific & UNP \\
\hline $\mathbf{3 3}$ & Utilities & Ticker \\
\hline 1 & Exelon & EXC \\
\hline 2 & NiSource & NI \\
\hline 3 & American Electric Power & AEP \\
\hline 4 & Vectren & VVC \\
\hline 5 & CenterPoint Energy & CNP \\
\hline & &
\end{tabular}

\section{Applying Ohlson (1995) Model to "Just Companies"}

Value generation is the main purpose of a business, i.e., wealth generation for the stakeholders, which results in efficient resource allocation. Value generation is dependent on the prudent decisions made by the management of the company and execution of their strategy. CSR plays an important role in these corporate decisions.

According to the (Ohlson, 1995) residual income valuation (RIV) model, the present non-accounting information affects future abnormal earnings or residual income auto-regressively. In our case, it appears that the Just Capital Foundation's issues selected for ranking companies did affect future abnormal earnings or residual income as reflected in their stock prices The firm's market value equals its book value adjusted for current profitability (as measured by abnormal earnings) and future profitability (i.e., goodwill, as measured by other information). Figures presented below covering five representative companies from various sector of USA economy are the evidence of this.

We can clearly see the rise in the valuation of the company after their entrance in the Just Capital Foundation's "Just Company" ranking. The phenomenon is clearly visible in Aero Space, Automobiles and Parts, Banks, Building Material and Packaging, Industrial goods, Capital Markets, Chemicals, Commercial Support Services, Consumer and Diversified Finance, Household Goods and Apparel, Food and Drug Retailers, Food Beverage and Tobacco, Healthcare Equipment and Services, Health Care Providers, Personal Products, Insurance, Internet, Computer and Services, Commercial Vehicles and Machinery, Media, Pharmaceutical and Biotech, Retail, Software, Technology 
Hardware, Telecommunication, Transportation and Utilities. This validates one of our initial hypothesis that markets value social responsibility efficiently. For the purpose of brevity, we are presenting only five graphs covering Aero Space, Automobiles \& Parts, Building Materials \& Packaging, Capital Markets and Chemicals (interested readers can request the rest of the graphs by contacting the author).

4.1 Aero Space

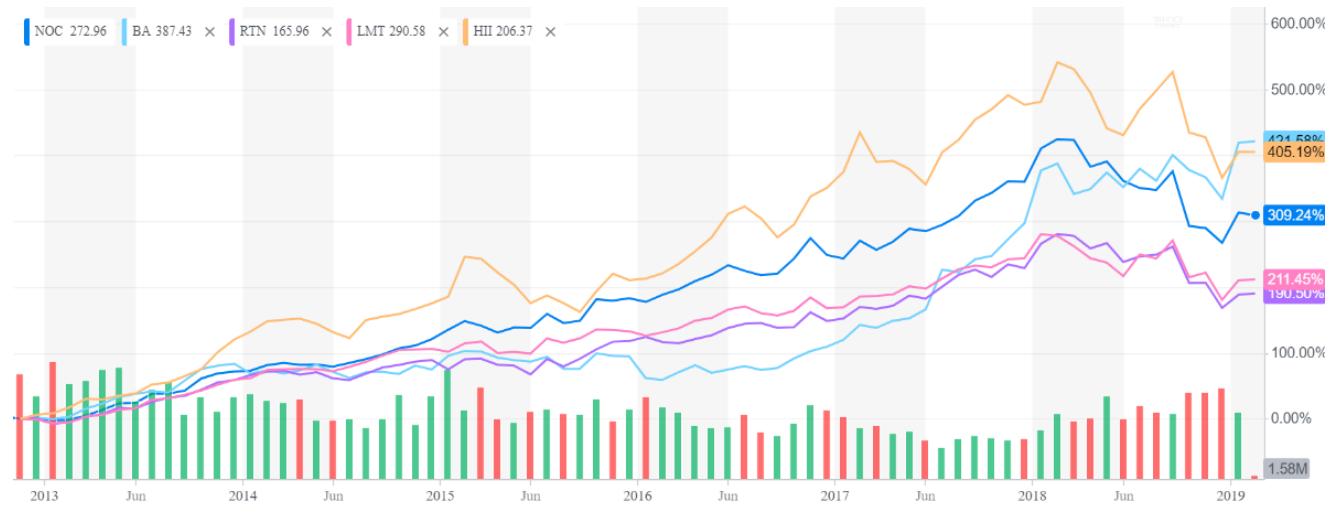

\subsection{Automobile \& Parts}

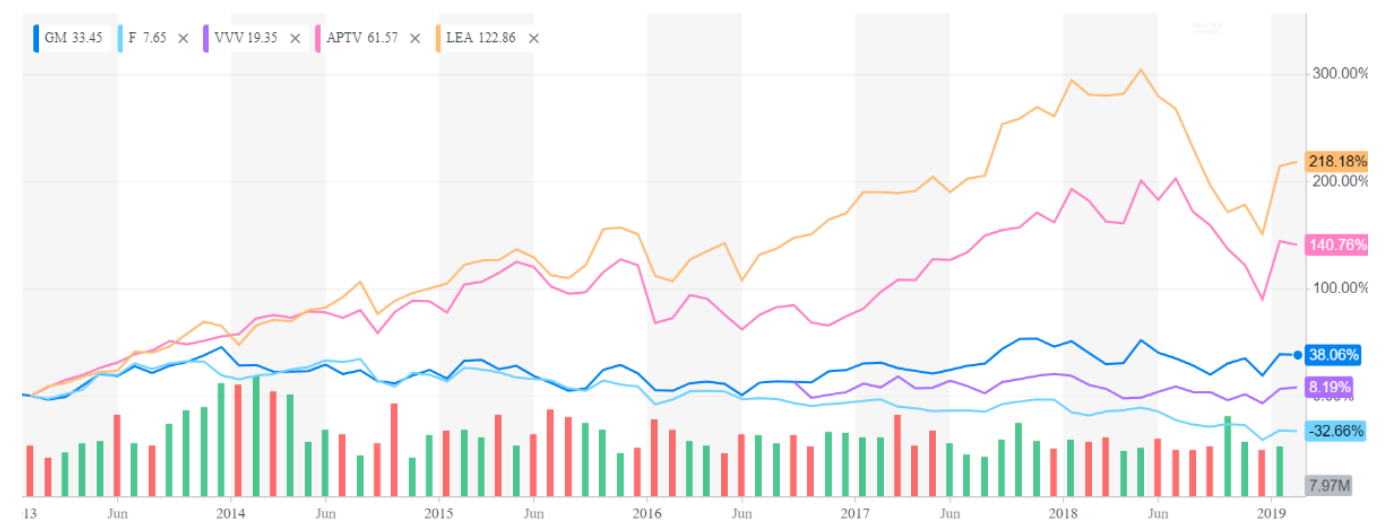

\subsection{Building Material and Packaging}

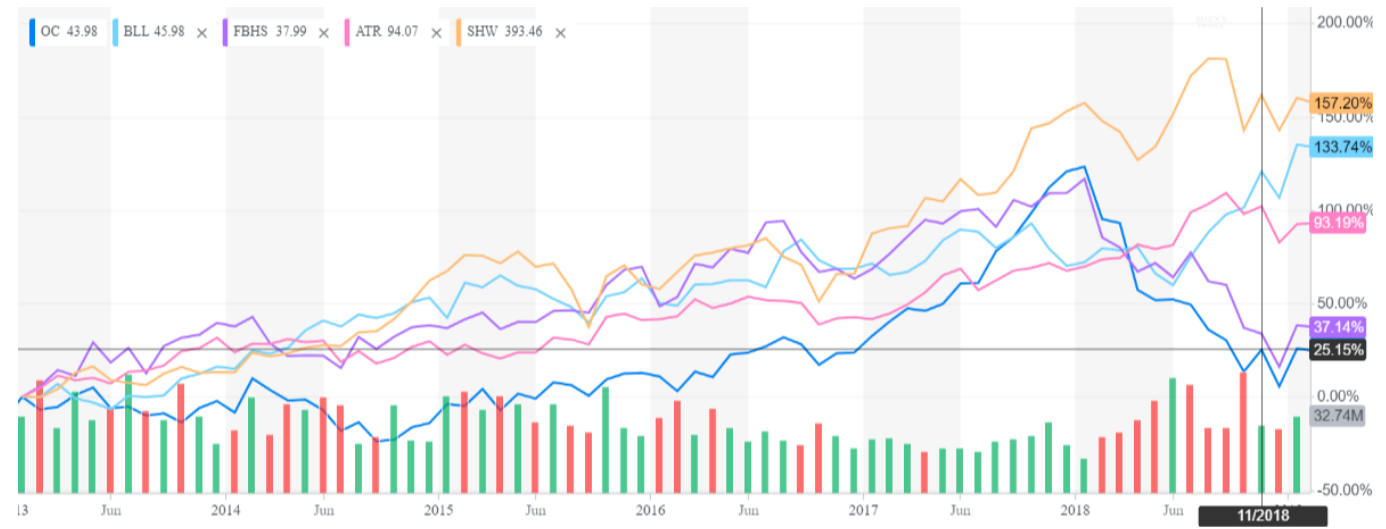




\subsection{Capital Markets}

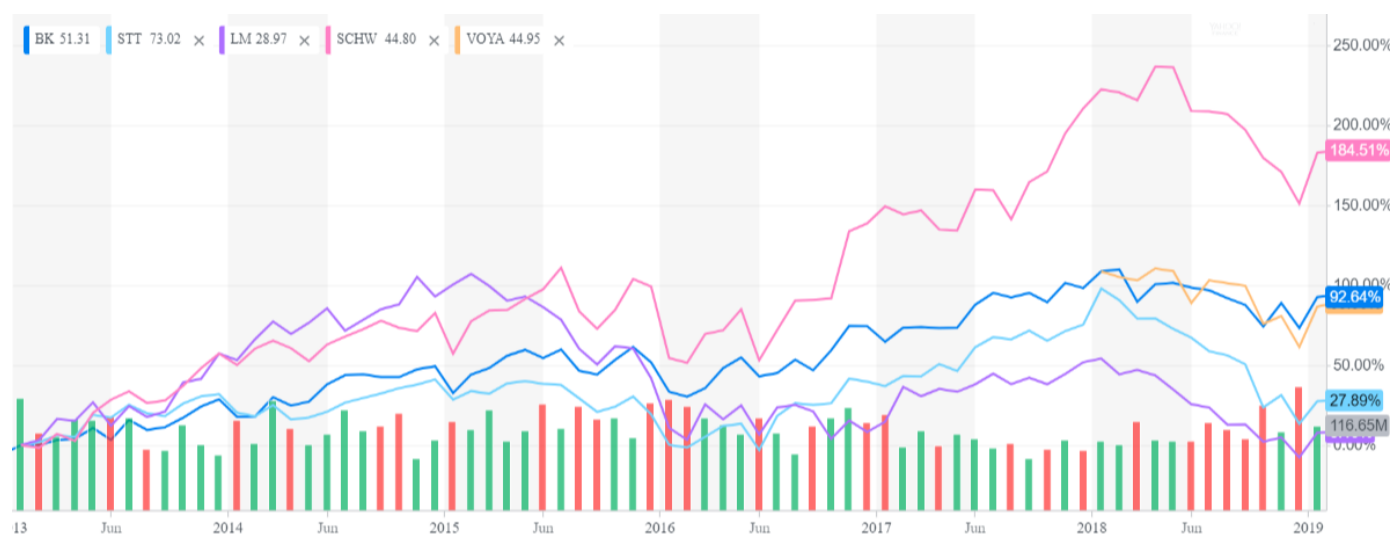

\subsection{Chemicals}

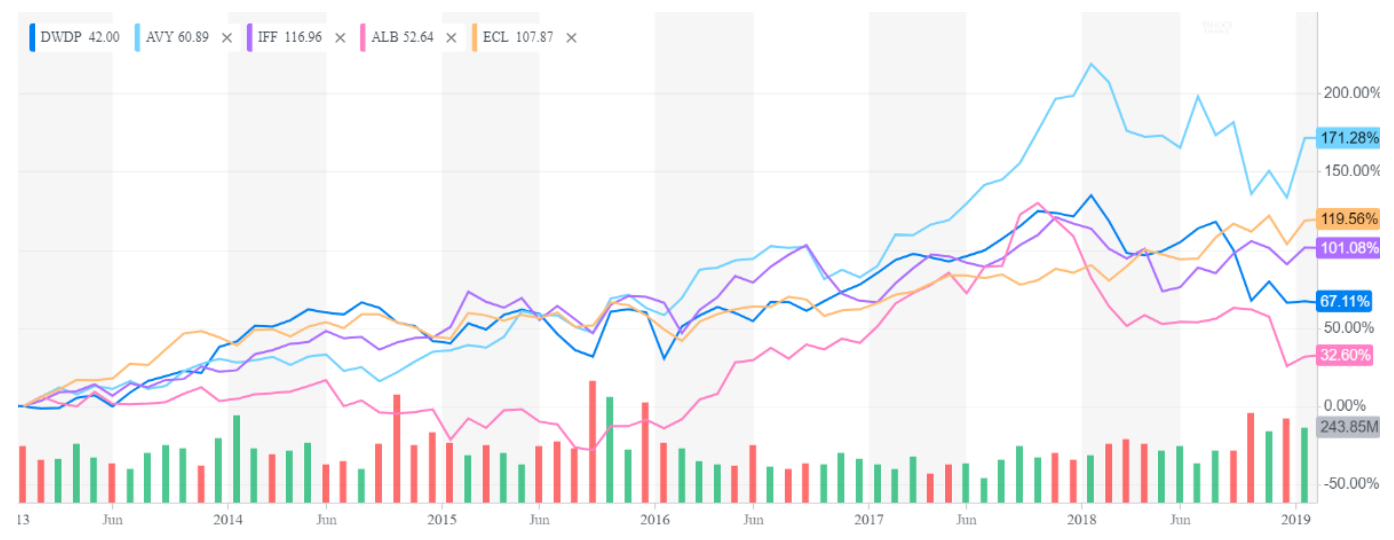

\section{Summary and Conclusion}

In this paper, we present and highlight the importance of CSR to corporate valuation. First, we establish this link through academic literature and later discuss it through corporate examples covering all the industrial sectors of USA economy.

Both the historical performance of a business and its valuation depend on how financial and operating risks are managed. CSR plays a critical role in the identification and management of such risks. This function can improve performance and create intangible value. The intangible value created in the present period is reflected in future market values (see (Ohlson, 1995)). We argue that increase in value, in our case, is due to the listing of companies in the "just Company" index. Hence, in valuing companies without considering the influence of the CSR, we may be ignoring an important source of risk and/or risk mitigation that materially affects value.

This paper highlights the importance of CSR for valuation of companies and documents the fact that benefits gain through CSR are real and may affect valuation. In the age of social media and digital economy, the words of mouth play a vital role in establishing the image of firm among masses. The voluntary CSR activities help companies to improve their image by engaging in social good.

The present work has many limitations. One of them is data accessibility and availability. The present data is from Yahoo!Finance. The results obtained in this work can further be improved by using the data from Bloomberg and Thomson Reutres databases. The results presented in this paper are our initial findings and should be interpreted with caution.

This work sets a stage for researchers to investigate whether the phenomenon of CSR has an impact on valuation of 
companies in different economies and geographic regions of the world (e.g., Europe and emerging markets) and whether that valuation impact is the same as in USA.

The results obtained in this paper may be of the interest for analysts, academic researchers, governments and regulatory bodies. In addition, we suggest that the results may indicate an area into which valuation professionals should invest time and thought as they assess the values of privately-held companies.

\section{References}

ACCA. (2015). The Eurpean commission's multi stakeholder forum on corporate social responsibility. Retrieved from https://www.accaglobal.com/ie/en/technical-activities/technical-resources-search/2015/february/ec-forum-on-cs r.html

Alikaj, A., Nguyen, C., \& Medina, E. (2017). Differentiating the impact of CSR strengths and concerns on firm performance: an investigation of MNEs and US domestic firms. Journal of Management Development, 36(3), 401-409. https://doi.org/10.1108/JMD-04-2016-0058

CFA Institute. (2018). INVESTMENT Firm of the Future. CFA Institute.

Cheng, B., Ioannou, I., \& Serafeim, G. (2014). Corporate social responsibility and access to finance. Strategic Management Journal, 35(1), 1-23. https://doi.org/10.1002/smj.2131

Cheung, Y. (2010). Does corporate social responsibility matter in Asian emerging markets?. Journal of Busines Ethics, 92(3), 401-403. https://doi.org/10.1007/s10551-009-0164-3

Dechow, P., Hutton, A., \& Sloan, R. G. (1999). An empirical assessment of the residual income valuation model. Journal of Accounting and Economics, 26, 1-34. https://doi.org/10.1016/S0165-4101(98)00049-4

Edward, E., \& Bell, P. (1961). The Theory and measurement of Business Income. University of California press.

Famiyeh, S. (2017). Corporate social responsibility and firm's performance: empirical evidence. Social Responsibility Journal, 13(2), 390-406. https://doi.org/10.1108/SRJ-04-2016-0049

Forbes; Just capital Foundation. (2018). The Just 100. Fobes. Retrieved from https://www.forbes.com/just-companies/\#56298e4b2bf0

Godfrey, P., Merrill, C., \& Hansen, J. (2009). The relationship between corporate social responsibility and shareholder value: An empirical test of the risk management hypothesis. Strategic Management Journal, 30, 425-445. https://doi.org/10.1002/smj.750

Horváthová, E. (2010). Does environmental performance affect financial performance? A meta analysis. Ecological Economics, 70, 52-59. https://doi.org/10.1016/j.ecolecon.2010.04.004

Lankoski, L. (2000). Determinants of environmental profit. An analysis of firm-level relationship between environmental and economic performance. Helsinki University of Technology Institute of Strategy and International Business Doctoral Dissertatio (p. 188).

Marsat, S., \& William, B. (2011). CSR and Market Valuation: International Evidence. https://doi.org/10.2139/ssrn.1833581

McGrath, M., \& Konrad, A. (2018). A Surprising Push By The Invisible Hand: Why More Companies Are Doing Better By Being Good. Forbes.

McWilliams, A., \& Siegel, D. (2001). Corporate social responsibility: a theory of the firm perspective. Academy of Management Review, 26(1), 117-127. https://doi.org/10.5465/amr.2001.4011987

Oeyono, J., Samy, M., \& Bampton, R. (2011). An examination of corporate social responsibility and financial performance. Journal of Global Responsibility, 2(1), 100-112. https://doi.org/10.1108/20412561111128555

Ohlson, J. A. (1995). Earnings, Book Values, and Dividends in Equity Valuation. Contemporary Accounting Research, 11(2), Spring, 661-687. https://doi.org/10.1111/j.1911-3846.1995.tb00461.x

Park, S. (2017). Corporate social responsibility, visibility, reputation and financial performance: empirical analysis on the moderating and mediating variables from Korea. Social Responsibility Journal, 13(4), 856-871. https://doi.org/10.1108/SRJ-01-2017-0012

Peasnell, K. (1982). Some formal connections between economic values and yields and accounting numbers. Journal of Business , Finance and Accounting, 9, 361-38. https://doi.org/10.1111/j.1468-5957.1982.tb01001.x 
Preinrich, G. (1938). Annual Survey of economic theory: the theory of depreciation. Econometrica, 6, 219-241. https://doi.org/10.2307/1907053

Stubes, M., \& Sun, L. (2010). Business reputation and labor efficiency, productivity, and cost. Journal of Business Ethics, 96(2), 265-283. https://doi.org/10.1007/s10551-010-0464-7

Wagner, M. (2001). A review of empirical studies concerning the relationship between environmental and financial performance. What Does the Evidence Tell Us (p. 52). Center for Sustainability Management.

Weber, M. (2008). The business case for corporate social responsibility: A company-level measurement approach for CSR. European Management Journal, 26, 247-261. https://doi.org/10.1016/j.emj.2008.01.006

Yu, Y., \& Choi, Y. (2014). Corporate social responsibility and firm performance through the mediating effect of organizational trust in Chinese firms. Chinese Management Studies, 8(4), 577-592. https://doi.org/10.1108/CMS-10-2013-0196

Zak, A. (2015). Triple bottom line concept intheory and practice. Research Papers of the Wroclaw University of Economics / Prace Naukowe Uniwersytetu Ekonomicznego We Wroclawiu, (387), 251-264. https://doi.org/10.15611/pn.2015.387.21 